\title{
TEKNOLOGI SISTEM INTEGRASI TERNAK, TANAMAN, DAN IKAN PADA LAHAN PEKARANGAN DAN TEKNOLOGI PENGOLAHAN BAHAN MAKANAN GUNA PENINGKATAN PENDAPATAN KELUARGA DI DESA CANGKRINGTURI, SIDOARJO
}

\author{
Sukarjati $^{1}$, Tatang Sopandi ${ }^{2}$, Pungky Slamet WK ${ }^{3}$ \\ 1, 2, 3 Program Studi Biologi, FMIPA, Universitas PGRI Adi Buana Surabaya \\ Email : ${ }^{1}$ sukarjati@ymail.com, ${ }^{2}$ tatang_sopandi@yahoo.co.id, ${ }^{3}$ \\ slametswk@yahoo.com
}

\begin{abstract}
Objective of KKN-PPM is to overcome the problems encountered in the village Cakringturi that the low incomes, lack of knowledge and understanding of environmental management, especially land yard. The solution to solve the problem is to empower rural communities through land use courtyard with technology integration system of livestock, crops and fish and provide food processing technology skills.Methods: Counseling, Mentoring, Training. Result: K1 program: Land yard citizens have been utilized, Product Probiofish, Aquaponics, Raising catfish in the pond Bis, The Carambola Fruit Cultivation along the river, Product instant and syrup TOGA, Vertikultur. K2 program: Competition Fun Cake in early childhood, Competition Beuty and Hijab Class, Teaching in Early Childhood Educatio. K3 Program : : Tutoring for elementary school children, Work with the community service, Yasinan, tahlilan, \& diba'an, Assist Posyandu services. Distribution of poor rice, Visits to polindes, Decorating in early childhood classrooms, Coordination with Karangtaruna, A visit to the village, Assist village. Conclusion: The entire planning of the program, both the main program, additional, or auxiliary implemented very well and smoothly by all students of KKN PPM 2015. Society and village and community leaders strongly support KKN PPM program and community empowerment have been successfully carried out.
\end{abstract}

Keywords : Community EmpowermentCatfish in the pond bis, Aquaponics, Vertikultur, Star fruit cultivation, Instant and Syrup Toga.

\section{PENDAHULUAN}

Desa cangkringturi dibatasi oleh wilayah desa simogirang, sebelah selatan winoplintahan dan sebelah timur oleh desa jedong. Luas wilayah 111519 ha. Jumlah penduduknya sejumlah 2394 yang terdiri dari laki laki 1235 orang, perempuan 1159 orang. Pekerjaan sebagian besar petani, PNS 8 orang, ABRI 7 orang, wiswasta 11 orang. Desa cangkringturi terdiri atas 2 dusun yaitu dusun cangkring dan dusun Turi. Kondisi mitra sebagai berikut: banyak rumah warga yang 
pekarangannya belum termanfaatkan. Pekarangan tersebut ada yang luasnya kurang dari $100 \mathrm{~m}^{2}$, ada yang luasnya sekitar $300 \mathrm{~m}^{2}$ serta ada yang luas pekarangannya lebih dari $300 \mathrm{~m}^{2}$. Pekarangan rumah hanya ditanami tanaman yang berfungsi hanya sebagai hiasan yang tidak terarah pada kebutuhan pangan keluarga serta hanya ditanam pada pinggiran rumah sehingga banyak lahan pekarangan yang kosong. Jenis tanah di desa cangkringturi tergolong kering walaupun pada daerah tertentu terdapat lahan persawahan. Kesadaran warga terhadap pengelolaan lingkungan terutama pekarangan rumah sangat rendah. Warga tidak memahami potensi desa yang dapat dikelola dan dapat digunakan untuk menambah perekonomian keluarga. Banyak limbah pertanian yang hanya terbuang begitu saja tanpa dimanfaatkan. Begitu juga dengan potensi limbah peternakan. Sampah rumah tangga hanya dibakar atau dibuang di sungai. Sepanjang lahan pinggiran sungai di biarkan terbengkalai. Permasalahan lain yang ditemukan adalah penguasaan teknologi untuk mengelola potensi desa masih kurang. Untuk itu diperlukan pengetahuan, pemahaman dan ketrampilan teknologi tepat guna sehingga warga mampu mengelola potensi desa terutama lahan pekarangan rumah guna pemenuhan kebutuhan pangan keluarga secara mandiri dan menambah penghasilan keluarga melalui teknologi pengolahan bahan makanan.

\section{METODE PELAKSANAAN}

Pembekalan Instuisi yang bertujuan untuk mempersiapkan mahasiwa untuk dapat memahami infrastruktur serta kehidupan masyarakat Desa Cangkring Turi. Adapun materi pembekalan tersebut dibagi 2 yaitu materi umum dan materi substansi. Materi umum disajikan dalam bentuk teori meliputi: KKN PPM sebagai salah satu wujud implementasi tridharma PT. Wawasan kebangsaan, Etika dan tata krama di masyarakat. Pemerintahan desa. Pelaksanaan KKN-PPM. Materi substantif diberikan secara teori dan praktek meliputi: Teknologi budidaya tanaman dengan sistem vertikultur, Aquaponik, Teknologi budidaya lele sistem kolam Bis, Teknologi pembuatan toga instan dan sirup toga.

Penerjunan: Melaksanakan Program $\mathrm{K} 1, \mathrm{~K} 2, \mathrm{~K} 3$.

Metode: Pelatihan, Penyuluhan, Pendampingan. 


\section{HASIL DAN PEMBAHASAN}

\section{HASIL}

Telah dilakukan Sosialisasi dan pemaparan materi ke Warga Desa tentang:Budidaya tanaman Belimbing Madu di sepanjang bantaran sungai dan penanaman belimbing madu di bantaran sungai . Telah dilakukan sosialisasi Budidaya Ikan Lele pada Bis sumur, dan pembuatan kolam Bis dan penaburan benih ikan lele, Pembuatan Pembuatan Probiotik, Pembuatan Toga Instan, Pembuatan sirup Toga, Telah dilakukan sosialisasi aquaponik dan pembuatan aquaponik. Telah dilakukan sosialisasi dan pembuatan vertikultur. Disamping itu telah dilaksanakan program mengajar di PAUD, Hijab Class, dan lomba fun cake. Pada program ini juga dilakukan pemberian les pada siswa SD, kerja bakti, yasin dan tahlil, mengecat balai desa, membantu di posyandu, melatih baris berbaris, mengikuti lomba 17 agustus, lomba gerak jalan sekecamatan, kunjungan ke setiap RT, Kunjungan ke Karang taruna, dan lain lain.

Pelaksanaan KKN PPM di Desa Cangkring Turi mempunyai dampak positif yaitu (1) termanfaatkannya lahan pekarangan warga untuk memenuhi kebutuhan.pangan keluarga dan tertatanya lingkungan yang sehat. (2). Meningkatnya kemampuan dan pengetahuan warga tentang budidaya ikan lele dalam kolam Bis.(3). Meningkatnya Pengetahuan warga tentang pembuatan probiofish .(4) Meningkatnya pengetahuan dan kemampuan warga dalam budidaya Belimbing Madu dan pengolahan pascapanen Belimbing Madu (5).Terjadinya peningkatan ekonomi warga melalui berkembangnya usaha ekonomi produktif keluarga.(6). Mampu membuat toga instan dan sirup toga. (7).Meningkatnya berpartisipasi warga dalam mengelola lingkungan

\section{PEMBAHASAN}

\section{Konsep Sistem Integrasi Ternak,}

\section{Tanaman dan Ikan}

Sistem Integrasi ternak, tanaman dan ikan adalah intensifikasi sistem melalui pengelolaan sumberdaya alam dan lingkungan secara terpadu dengan komponen ternak, tanaman dan ikan. Tujuan pengembangan sistem ini adalah untuk meningkatkan produktivitas dan kesejahteraan masyarakat (Hardianto, 2008). Ciri utama integrasi ternak, tanaman dan ikan adalah adanya sinergisme atau keterkaitan yang saling menguntungkan antara tanaman, ternak 
dan perikanan. Kotoran ternak dimanfaatkan sebagai pupuk organik untuk tanaman, dan memanfaatkan limbah pertanian untuk pakan ternak dan pakan ikan. Pemanfaatan kotoran ternak sebagai pupuk organik disamping mampu menghemat penggunaan pupuk anorganik, juga sekaligus mampu memperbaiki struktur dan ketersediaan unsur hara tanah. Pada sistem integrasi ini masalah ketersediaan pakan dengan memanfaatkan limbah pertanian seperti jerami padi, jerami jagung akan mampu meningkatkan ketahanan pakan khususnya pada musim kemarau, disamping itu juga mampu menghemat tenaga kerja dalam kegiatan mencari rumput sehingga memberi peluang waktu untuk kegiatan yang lain.

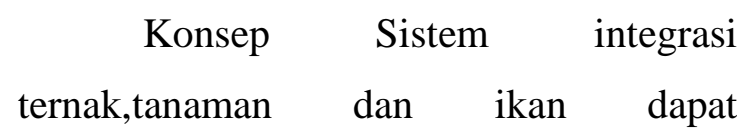
dikembangkan pada lahan terbatas maupun lahan luas. Pada lahan terbatas atau lahan sempit konsep ini menjadi sangat tepat dikembangkan dengan pola intensifikasi lahan. Lahan sempit akan memberikan produksi maksimal tanpa ada limbah yang terbuang percuma. Sedangkan untuk lahan lebih luas konsep ini akan menjadi suatu solusi mengembangkan usaha yang lebih menguntungkan. Melalui sistem yang terintegrasi ini akan bermanfaat untuk efisiensi penggunaan lahan, optimalisasi produksi, pemanfaatan limbah.

\section{Keunggulan sistem integrasi ternak,} tanaman dan Ikan

Pada prinsipnya pergertian terintegrasi adalah bagaimana sistem pengelolaan limbah peternakan dan pertanian dapat memberikan kontribusi hubungan timbal balik antara limbah sebagai bahan sisa proses di satu sisi dan limbah sebagai sumberdaya yang dapat dimanfaatkan disisi lain.

Soehadji (1992) menyatakan, bahwa limbah peternakan umumnya meliputi semua kotoran yang dihasilkan dari suatu kegiatan usaha peternakan, baik berupa limbah padat dan cairan, gas, ataupun sisa pakan. Limbah peternakan adalah semua buangan dari usaha peternakan yang bersifat padat, cair, dan gas. Menurut Juheini dan Sakryanu (1998), sebanyak 56,67 persen peternak membuang limbah ke badan sungai tanpa pengelolaan, sehingga terjadi pencemaran lingkungan. Limbah peternakan sering menimbulkan berbagai protes dari kalangan masyarakat sekitarnya,terutama rasa gatal ketika menggunakan air sungai yang tercemar, di samping bau yang 
sangat menyengat. Bila limbah ini dikelola dengan baik dapat memberikan nilai tambah. Salah satu upaya untuk mengurangi limbah adalah memanfaatkan limbah tersebut untuk pembuatan kompos. Upaya memadukan tanaman, ternak dan ikan di lahan pekarangan memiliki manfaat ekologis dan ekonomis. Dengan pemanfaatan dan pengolahan limbah, maka sustainable atau keberlangsungan ketersediaan pakan dan pupuk dapat terus terjaga dan tidak ada kekhawatiran kekurangan pakan dan pupuk untuk pertanian. Dalam memanfaatkan limbah pertanian yang ada, diperlukan teknologi dan rekayasa proses sehingga proses pengolahan limbah menjadi pupuk dan pakan akan tepat pada sasaran. Pengolahan limbah menjadi pakan tetap memperhatikan nutrisi untuk ternak, kemudahan proses, biaya yang rendah dan kontinuitas. Dengan termanfaatkannya jerami sebagai pakan ternak dan kotoran ternak sapi untuk diproses menjadi pupuk organic maka tidak ada limbah yang terbuang.

\section{KESIMPULAN}

Seluruh perencanaan program, baik program utama, tambahan, maupun bantu dilaksanakan dengan sangat baik dan lancar oleh seluruh mahasiswa KKN-PPM 2015. Masyarakat dan perangkat desa serta tokoh masyarakat sangat mendukung program KKN PPM dan pemberdayaan masyarakat telah berhasil dilakukan. Adapun Produk yang dihasilkan pada kegiatan KKN PPM ini adalah Produk Probiofish, Aquaponik, Budidaya ikan lele pada kolam Bis, Budidaya Belimbing madu di bantaran sungai, Produk toga instan dan sirup toga, Vertikultur

\section{DAFTAR PUSTAKA}

Hardianto, Rully, 2008, Pengembangan

Teknologi Sistem Integrasi Tanaman-

Ternak

model Zero waste,

\section{http://porotani.wordpress.com}

Juheini, N dan Sakryanu, KD. 1998.

Perencanaan Sistem Usahatani Terpadu

dalam Menunjang Pembangunan

Pertanian yang Berkelanjutan : Kasus

Kabupaten Magetan, Jawa Timur.

Jurnal Agro Ekonomi (JAE) Vol. 17 (1)

Soehadji, 1992. Kebijaksanaan

Pemerintah dalam Pengembangan

Industri Peternakan dan Penanganan

Limbah Petemakan. Makalah Seminar. 
Direktorat Jenderal Peternakan.

Departemen Pertanian. Jakarta

Direktorat Jenderal Peternakan. 2010.

Pedoman Teknis Pengembangan Usaha

Integrasi Ternak Sapi dan Tanaman.

Direktorat Jenderal Peternakan

Kementerian, Pertanian, Jakarta 